\title{
Budget block on US bid to rejoin Unesco...
}

[WASHINGTON] A bid by the State Department to renew US membership of the United Nations Educational, Scientific and Cultural Organization (Unesco) has been blocked by the White House budget office.

The State Department had opened its effort to secure US re-entry with a request to the White House's Office of Management and Budget (OMB) that $\$ 22$ million - three months' contributions to Unesco - should be included in the administration's budget request to Congress for the fiscal year 2000.

But the OMB, which is said to remain sceptical of the chances of such a request getting past the Republican-dominated Congress, has omitted it from its advice to President Bill Clinton on the budget.

Various Democrat members of Congress, scientific bodies and organizations sympathetic to US re-entry into Unesco, and angered by the OMB's move, are appealing to Clinton to reinstate the Unesco allocation in his budget document, which will be submitted to Congress at the end of January.

Esteban Torres (Democrat, California), for example, a former US ambassador to Unesco, has written to Clinton advising him that the United States "can no longer afford to remain outside of Unesco".
Supporters of US re-entry argue that dropping the budget request could damage US interests in international science and education policy. This includes participation in the election of a new director general for the agency; plans for Unesco's post-2000 strategy; and preparations for and participation at next year's Unesco World Conference on Science in Budapest (see Nature 396, 299; 1998).

John Fobes, a former deputy director general of the agency who now chairs Americans for Universality of Unesco, says that the conference is too important for the United States to participate as an observer. "A mere announcement [that the United States is preparing to rejoin Unesco] would make a lot of waves," says Fobes. It would, he adds, effectively change the country's status from observer to full member.

The United States under Republican President Ronald Reagan walked out of Unesco in 1984 complaining that the agency was being mismanaged and lacked a clear focus.

Clinton gave a public undertaking on the fiftieth anniversary of Unesco in 1995 that the United States would rejoin, arguing that he was satisfied that key management reforms had been implemented. But he gave no clear indication of timing.

The State Department's decision to push for US re-entry at this time has, however, surprised some close observers of relations between the United States and the United Nations, as Unesco is not considered to be top priority in the list of pending issues between the two.

Reversing the US withdrawal from the United Nations Industrial Development Organization (UNIDO) in 1996 is considered to be a higher political priority than rejoining Unesco.

Republican opposition has also stalled a proposed settlement in Congress of the United States' unpaid arrears to the UN, which are close to $\$ 1$ billion. One UN observer in Washington DC says that additional requests for UN contributions "will be received quite violently in some quarters".

The State Department has a strong ally in its efforts. Britain chose to rejoin last year after a similar absence, and is believed to be encouraging the United States to do the same. "Don't underestimate the power of [Tony] Blair going in," says one senior Unesco official. "The United States does not like to see itself alone."

EhsanMasood

\section{as Australian minister hits out at agency over heritage sites}

[SYDNEY] Australia's environment minister, Robert Hill, has come into conflict with non-government scientists over whether extra steps are needed to protect two of Australia's main environmental attractions.

The government is facing opposition to its decision to allow uranium mining in the Kakadu National Park in the Northern Territory. It is also under fire for its failure to take a firm stand on global warming, which, argue critics, is threatening the health of the Great Barrier Reef.

The government is rejecting demands that these areas, already featured as World Heritage Areas by Unesco, be placed on the Unesco 'endangered' list.

One of the disputes arose from a Unesco investigation into the damage that could be caused by the development of a uranium mine and mill at Jabiluka in Kakadu, which was approved by the government after years of opposition.

Environmental activists, the local aboriginal Mirrar people and many scientists, joined last week by the Australian Catholic Social Justice Council, argue that the mine would irrevocably damage the World Heritage values of the park.

The Unesco mission concluded that the park "is exposed to serious threats which are placing it under both ascertained and

606

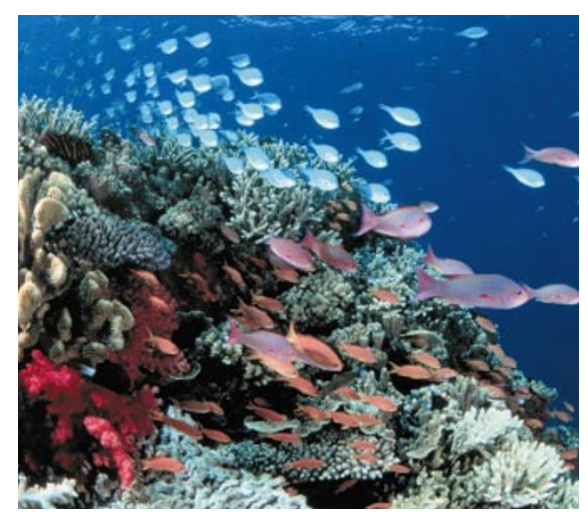

Coral crisis: researchers have raised the alarm at Unesco over threats to the Great Barrier Reef.

potential danger". Hill, a lawyer, has accused the mission of bias, lack of balance and factual errors. The mission, led by Francesco Francioni, an Italian environmental lawyer who also chairs the World Heritage Committee, recommended that the Jabiluka project should not proceed.

In its report, presented to the Bureau of the World Heritage Committee at its meeting in Kyoto, Japan, two weeks ago, the mission said that its recommendations "should be implemented in a spirit of full transparency and public consultation in Australia". But the committee offered
Australia six months in which to present fresh evidence against a formal "threatened" label.

Construction of the uranium mine has been proceeding rapidly following a High Court rejection of an appeal by aboriginal groups.

In a separate issue, Hill characterized as "not compelling" recent evidence linking world-wide coral bleaching to rises in sea surface temperatures (see Nature 396, 10; 1998). His statement in parliament followed the release last month of a report on the status of the world's coral reefs by the Global Coral Reef Monitoring Network, an initiative of Al Gore, the US Vice-President.

The report concludes that reefs are "under considerable stress and are experiencing considerable damage" in association with rises in temperatures.

Frank Talbot of Sydney's Macquarie University, director emeritus of the Smithsonian Museum of Natural History in Washington DC, has joined other reef researchers in appealing to Unesco to reexamine its World Heritage listing of the Great Barrier Reef as a result of the effects of land clearing, coastal developments and overfishing. Otherwise, they predict "the slow death of the greatest exemplar of coral reefs in the world".

Peter Pockley 